\title{
PHYSIOLOGICAL RESPONSE OF NATIVE ECOTYPES OF CLADOPHORA GLOMERATA (L.) KÜTZING (CHLOROPHYCEAE) IN RELATION TO SALINITY
}

\author{
Mohamed S. M. Abdel-Kareem* and Maha M. Allam** \\ Department of Botany, Faculty of Science, University of Alexandria, Egypt
}

\begin{abstract}
The effect of different salinities on intracellular minerals, total carbohydrates, soluble sugars, insoluble sugars, ammonia, amides, nitrates, proline, protein and total nitrogen contents of Cladophora glomerata was studied. The results revealed that osmoregulation mechanism in this species was only in part via mineral ions concentrations and mainly via proline production. The results suggest Cladophora glomerata as a "salinity generalist" species (a species that able to maintain fitness in a wide range of salinities).
\end{abstract}

Key words: Cladophora glomerata, physiological response, ecotypes, salinity.

\section{Introduction}

Phenotypic plasticity is the ability of an individual organism to alter its physiology and morphology in relation to changes in environmental conditions (Schlichting, 1986). By the early 1990's, developmental and physiological plasticity had been reported in plants, marine organisms, insects, reptiles, small mammals (Sultan, 1995) and lichens (Pintado et al., 1997). However differences in physiological plasticity have been demonstrated in response to changes in, nutrient concentrations for microalgae (Fabergas et al., 1986), salinity for Skletonema costatum (Rijstenbil et al., 1989a), salinity for Ditylum brightwellii (Rijstenbil et al. 1989b) salinity for Enteromorpha intestinalis (Allam, 1994) and salinity and inorganic nitrogen sources for Dunaliella salina and Chlorella salina (Abdel-Kareem, 1997).

Few originally marine algae have been succeeded in conquering pure fresh water habitats. The diatom Hyrosera triquetra, the red alga Caloglossa agaswgraensis (Simonsen, 1965), the brown alga Ectocarpus siliculosus (Russel and Balton, 1975) and the green alga Enteromorpha intestinalis (Allam, 1989; Martins et al., 1999; Kamer and Fong, 2000) live in marine water, but can migrate to fresh water or water fall.

Full realization of algal potentialities to overcome the salinity problem will not be achieved until our understanding of their physiological responses to salt stress is intensively studied. So, this work aims to evaluate the physiological responses of Cladophora glomerata in relation to salinity stress and to assess the 
metabolites that will be stimulated to carry out the osmoregulatory mechanisms in this species.

\section{Materials and Methods}

\section{Algal material and water sampling}

Cladophora glomerata was collected from three habitats representing fresh water, estuarine and marine environments at El-Max locality, Alexandria Egypt. The marine sample was collected from the sea, the estuarine sample from the junction between the sea and Lake Mariut under El-Max Bridge while the fresh water sample from the lake itself. Water samples were taken from the same sites; subsurface water samples were collected in polyethylene bottles and conveyed to the laboratory for analysis.

\section{Culturing}

The collected algal materials were maintained under laboratory conditions in their natural bathing medium supplied with enriching solution (Boalch, 1961) and two antibiotic mixture (Stein, 1973) in a large aquarium with good aeration for acclimation. The acclimatized axenic progeny of these plants were used as the starting inocula for culture purposes. The samples were cultured in 1 liter capacity flat bottom flasks equipped with inlet and outlet tubes for aeration. Each culture flask contained $500 \mathrm{ml}$ enriched sterilized water of the appropriate salinity and $2 \mathrm{~g}$ of axenic fresh algal material. The cultures were vigorously aerated with air containing approximately $0.5 \% \mathrm{CO}_{2}$ passed through sterilized gamma 12 filter units to prevent bacterial contamination. The culture cabinet was provided with cooling unit to adjust the temperature at $25^{\circ} \mathrm{C}$ and light was supplied by 6 fluorescent lamps giving a total light intensity of $80 \mu \mathrm{mol} \mathrm{m} \mathrm{m}^{-2}$ The light regime was $16 \mathrm{~h}$ light/ $8 \mathrm{~h}$ dark cycles and the flasks were illuminated from below. The algal materials used in biochemical analysis were collected at its exponential growth phase (data of growth curve not shown) after 6 days. Different grades of salinity were prepared by diluting double strength sea water (Starr, 1978).

\section{Biochemical analysis methods}

The amount of sodium, potassium and calcium in the algal material was determined according to the method described by Chapman (1976). The carbohydrate contents were assayed by the procedure described by Muratl et al. (1968). Ammonia was determined colorimetrically using the phenol method as reported by Booth and Lobring (1973). Amides and nitrates were determined according to Naguib (1964) and Johnson and Ulrich (1950) respectively. Free proline in water extract of the algal material was estimated as recommended by Bates et al. (1973), protein content was assayed by the method described by Hartee (1972) while the total nitrogen content assayed by the method described by Barakat et al. (1986). All experiments described were conducted 
independently twice with three replicates each, the mean values given in results representing averages of six assays.

\section{Results and Discussion}

Organisms are not just slaves to the physical environments, they adapt themselves and modify according to changes in these environments so as to reduce the limiting effects of environmental factors. Species with wide geographical ranges almost always develop locally adapted populations called ecological races or ecotypes that have optima and limits of tolerance adjusted to local conditions (Fretwell, 1972). Accordingly, we have three ecotypes of Cladophora glomerata grown naturally in three different salinity habitats: marine, estuarine and fresh water.

The analysis of water collected from these three habitats (Table 1) revealed that the total alkalinity, total hardness and calcium content are nearly the same in the three habitats. However, sea water was found to be the richest in the content of chloride, nitrate and magnesium followed by estuarine water then fresh water. Meanwhile, the estuarine water was the richest in silicate, while the fresh water was the richest in sulphate content. These variations, mainly in salinity, brought about a multitude of structural response mainly in body size, where there was a gradual decrease in body size from marine to estuarine and then to fresh water samples.

Table (1): Analysis of water in the three habitats of Cladophora glomerata.

\begin{tabular}{|c|c|c|c|}
\hline \multirow[b]{2}{*}{ Content of water sample } & \multicolumn{3}{|c|}{ Habitat } \\
\hline & $\begin{array}{c}\text { Sea } \\
\text { water }\end{array}$ & $\begin{array}{c}\text { Estuarine } \\
\text { water }\end{array}$ & $\begin{array}{l}\text { Fresh } \\
\text { water }\end{array}$ \\
\hline Total alkalinity $(\mathrm{g} / \mathrm{L})$ & 0.940 & 1.000 & 1.000 \\
\hline Chloride $(\mathrm{mg} / \mathrm{L})$ & $\mathbf{8 . 8 0 0}$ & $\mathbf{3 . 6 0 0}$ & 2.750 \\
\hline Nitrate $(\mathrm{mg} / \mathrm{L})$ & 0.120 & 0.050 & $\mathbf{0 . 0 2 0}$ \\
\hline Total hardness as carbonate $(\mathrm{g} / \mathrm{L})$ & 2.980 & 1.600 & 1.320 \\
\hline Hardness as Ca carbonate (g/LI) & $\mathbf{1 . 0 0 0}$ & 1.040 & 1.140 \\
\hline Hardness as Mg carbonate (g/L) & 1.980 & 0.560 & 0.180 \\
\hline Calcium $(\mathrm{g} / \mathrm{L})$ & 0.400 & 0.417 & 0.456 \\
\hline Magnesium $(\mathrm{g} / \mathrm{L})$ & 0.481 & 0.136 & 0.437 \\
\hline Sulphate (g/L) & 0.113 & 0.125 & 0.520 \\
\hline Silicate $(\mathrm{g} / \mathrm{L})$ & 3.000 & 4.000 & 2.000 \\
\hline Salinity \%o & 37.500 & 17.000 & 5.000 \\
\hline
\end{tabular}

When marine macroalgae subjected to increase or decrease in salinity, they are able to regulate their intracellular osmotic pressure by adjusting cellular ion concentrations $\left(\mathrm{K}^{+}, \mathrm{Na}^{+}, \mathrm{Ca}^{++}\right.$and $\left.\mathrm{Cl}^{-}\right)$and/or concentrations of organic solutes (Allam, 1989; Thomas et al., 1990; Kirst, 1990 and others). Evidently such variation plays a major role in enabling particular species to inhabit a variety 
of saline habitats. This is not absolutely true regarding ions contents in the three ecotypes in their natural habitats (Table 2). Although $\mathrm{Ca}^{++}$and $\mathrm{Cl}^{-}$contents were higher in the marine sample, it is not so for both $\mathrm{K}^{+}$and $\mathrm{Na}^{+}$contents. Meanwhile, highest $\mathrm{K}^{+} / \mathrm{Na}^{+}$ratio was recorded in estuarine sample, which suggest a special osmoregulatory mechanism to overcome salinity fluctuation characterizing its natural habitat, since plants with high $\mathrm{K}^{+} / \mathrm{Na}^{+}$ratio had wider salt tolerance (Thomas et al., 1990).

Table (2): Analysis of some carbohydrate, nitrogen and minerals fractions of the three ecotypes of Cladophora glomerata.

\begin{tabular}{|c|c|c|c|}
\hline \multirow[b]{2}{*}{ Fraction } & \multicolumn{3}{|c|}{ Algal ecotype } \\
\hline & $\begin{array}{c}\text { Sea } \\
\text { water }\end{array}$ & $\begin{array}{c}\text { Estuarine } \\
\text { water }\end{array}$ & $\begin{array}{l}\text { Fresh } \\
\text { water }\end{array}$ \\
\hline \multicolumn{4}{|c|}{ Carbohydrate fractions } \\
\hline Total carbohydrates $(\mu \mathrm{g} / \mathbf{1 0 0} \mathrm{g}$ fresh wt.) & 356.000 & 310.000 & 98.400 \\
\hline Soluble sugars ( $\mu \mathrm{g} / \mathbf{1 0 0} \mathrm{g}$ fresh wt.) & 22.080 & 19.480 & 10.920 \\
\hline Insoluble sugars $(\mu \mathrm{g} / 100 \mathrm{~g}$ fresh $\mathrm{wt})$. & 333.920 & 290.520 & 87.500 \\
\hline \multicolumn{4}{|c|}{ Nitrogen fractions } \\
\hline Ammonia ( $\mu \mathrm{g} / 100 \mathrm{~g}$ fresh wt.) & 0.900 & 2.800 & 2.600 \\
\hline Amides ( $\mu \mathrm{g} / 100 \mathrm{~g}$ fresh wt.) & 8.400 & 7.860 & 8.220 \\
\hline Nitrates $(\mu \mathrm{g} / 100 \mathrm{~g}$ fresh wt. $)$ & 2016.000 & 2284.000 & 3072.000 \\
\hline Soluble nitrogen (mg/g dry wt.) & 4.200 & 4.500 & 4.000 \\
\hline Insoluble nitrogen (mg/g dry wt.) & 5.800 & 3.000 & 48.000 \\
\hline Total nitrogen (mg/g dry wt.) & 10.000 & 7.500 & 52.000 \\
\hline Protein ( $\mu \mathrm{g} / 100 \mathrm{~g}$ fresh wt.) & 252.000 & 567.000 & 445.000 \\
\hline Proline ( $\mu \mathrm{g} / \mathbf{1 0 0} \mathrm{g}$ fresh wt.) & 2.400 & 1.800 & 0.600 \\
\hline \multicolumn{4}{|c|}{ Minerals fractions } \\
\hline Chloride ( $\mathrm{Cl}^{-} \mathrm{mg} / 100 \mathrm{~g}$ fresh wt.) & 30.700 & 27.300 & 24.800 \\
\hline Calcium $\left(\mathrm{Ca}^{++} \mu \mathrm{g} / \mathrm{g}\right.$ dry wt. $)$ & 126.780 & 73.940 & 77.460 \\
\hline Potassium $\left(\mathrm{K}^{+} \mu \mathrm{g} / \mathrm{g}\right.$ dry wt. $)$ & 29.720 & 35.480 & 33.270 \\
\hline Sodium $\left(\mathrm{Na}^{+} \mu \mathrm{\mu g} / \mathrm{g}\right.$ dry wt. $)$ & 106.960 & 107.960 & 105.860 \\
\hline $\mathrm{K}^{+} / \mathrm{Na}^{+}$ratio & 0.278 & 0.329 & 0.314 \\
\hline
\end{tabular}

Therefore, the osmoregulation mechanism in Cladophora glomerata was suggested to be only in part via mineral ions concentrations. This suggestion was supported by the results obtained when the alga cultivated in different salinities. Although there is a proportional relationship between salinity and $\mathrm{Cl}^{-}$content, the $\mathrm{K}^{+}, \mathrm{Na}^{+}$and $\mathrm{Ca}^{++}$concentrations increase gradually by increasing salinity up to $45 \%$ or $55 \%$ in most cases (Figure 1). However, the increase of salinity more 
Physiological response of native ecotypes of Cladophora glomerata (L.) Kützing (Chlorophyceae) in relation to..
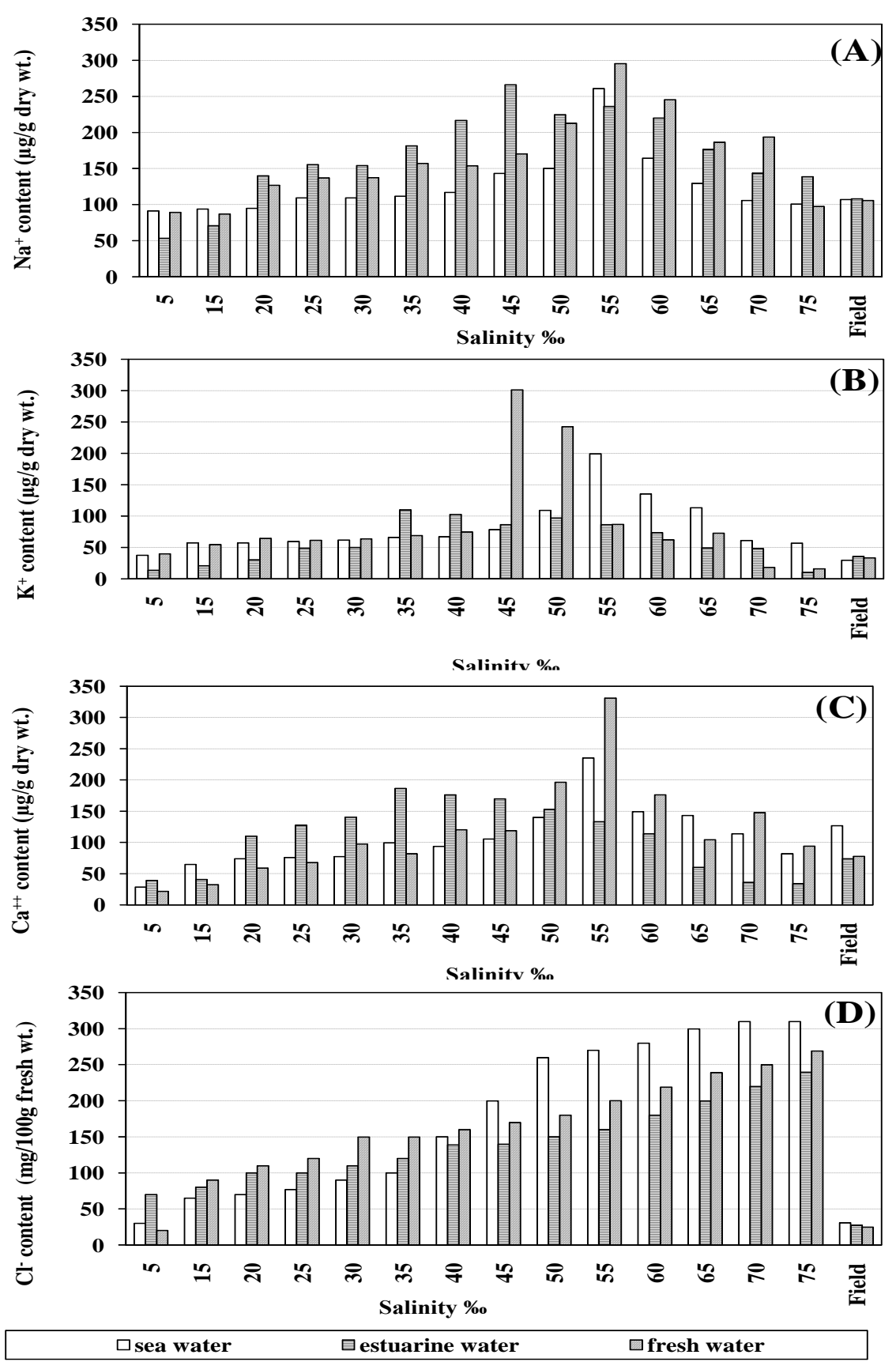

Figure 1. Effect of different salinities on the intracellular minerals contents of Cladophora glomerata collected from different habitats, (A) $\mathrm{Na}+,(B) \mathrm{K}^{++},(\mathrm{C}) \mathrm{Ca}^{++}$ and (D) $\mathrm{Cl}^{-}$. 
than $55 \%$ led to a decrease of $\mathrm{K}^{+}, \mathrm{Na}^{+}$and $\mathrm{Ca}^{++}$concentrations and led also to the interaction of another osmoregulator, proline (Figure 4).

Marine sample in its natural habitat showed higher proline content than both estuarine and fresh water ones, which provide physiological adaptation to local environmental salinity conditions. Meanwhile, cultivation in different salinities showed a proportional relationship between salinity and proline content in the three ecotypes. Proline accumulation may be considered either as an indicator of salt-induced water deficit or as a temporary deviation of the metabolic pathway from glutamic acid to proline (Imamul Hug and Larher, 1985). However, formation and degradation of proline could be regarded as one of the main osmoregulatory mechanisms necessary to maintain a suitable osmotic pressure within the cells of many algae (Allam, 1989; Abdel-kareem, 1997; AbdeRahman et al., 2005) and act as a compatible solute in the important role of balancing cytoplasmic and vacuolar water potential (Gorham, 1995; Gul and Khan, 2008).

On the contrary, protein content dropped with the elevation of salinity above $35 \%$ o (Figure 4). This may be due to increased synthesis of proline accompanied the breakdown of protein due to salinity stress. These results have been documented by many previous studies (e. g. Abdel-Basset, 1986; Allam, 1989; Abdel-Kareem, 1997). Total carbohydrate contents in plants cultured at all salinity variations (Figure 2) were always less than the results obtained from native field plants. However, the content of total carbohydrates in cultivation was found to be higher in marine than both estuarine and fresh water samples. Samples of all habitats showed a marked decrease in the content of total carbohydrates, soluble and insoluble sugars when cultured at higher salinity levels (40-50\%). The decrease in the content of insoluble sugars due to salinity stress was recorded in many algae belonging to different groups (e. g. Rijstenbil et al., 1989 a \& b; Karestn and Kirst, 1989 \& 1990). This may interpreted to the inhibitory effect of high salinity upon photosynthetic process. Meanwhile, the decrease of soluble sugars because of salinity stress could be due to photosynthesis and/or respiration inhibition (Ziska and Teramura, 1992; Larkum and Wood, 1993; Ekelund, 2000).

The content of nitrogen fractions (ammonia, amides, nitrates, protein and total nitrogen) of the cultured species showed the highest values mostly at 35\%o salinity and in part at 40\%o salinity (Figures 3 and 4). Increasing salinity above $40 \%$ led to markedly drop in these fractions, results parallel to those of carbohydrate contents (Figure 2). This drop of fitness contents due to salinity stress could suggest being the cost of plasticity.

Costs of plasticity were detected in low percentage of cases (Van Kleunen and Fischer, 2005 and 2007), this may indicate that costs are rare or difficult to detect. The fact that plasticity observed in nature is often lower than expected 
Physiological response of native ecotypes of Cladophora glomerata (L.) Kützing (Chlorophyceae) in relation to..
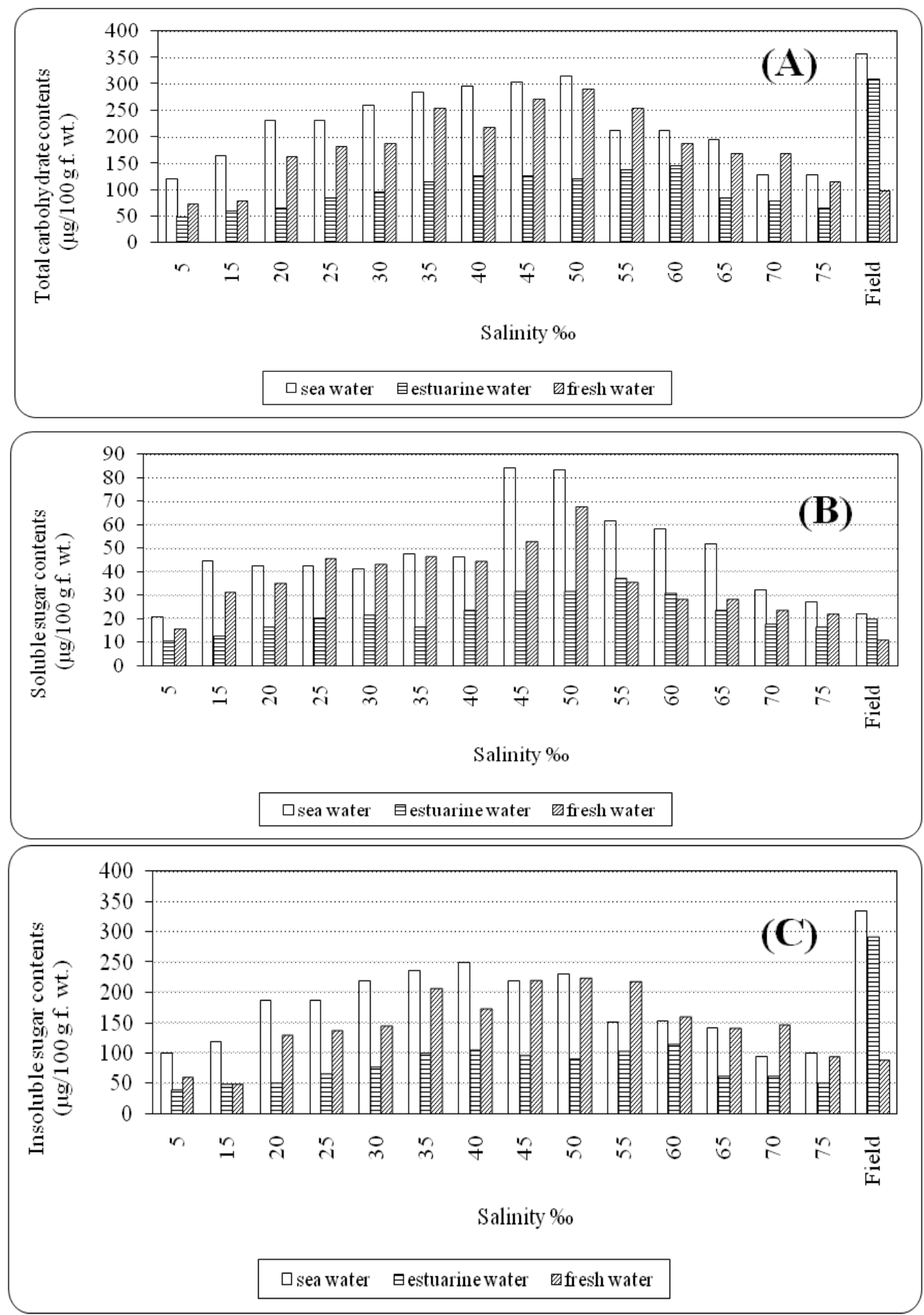

Figure 2. Effect of different salinities on total carbohydrates (A), soluble sugars (B) and insoluble sugars (C) contents of Cladophora glomerata collected from different habitats.

Egyptian J. of Phycol. Vol. 9, 2008

- 121 - 
Mohamed S. M. Abdel-Kareem and Maha M. Allam
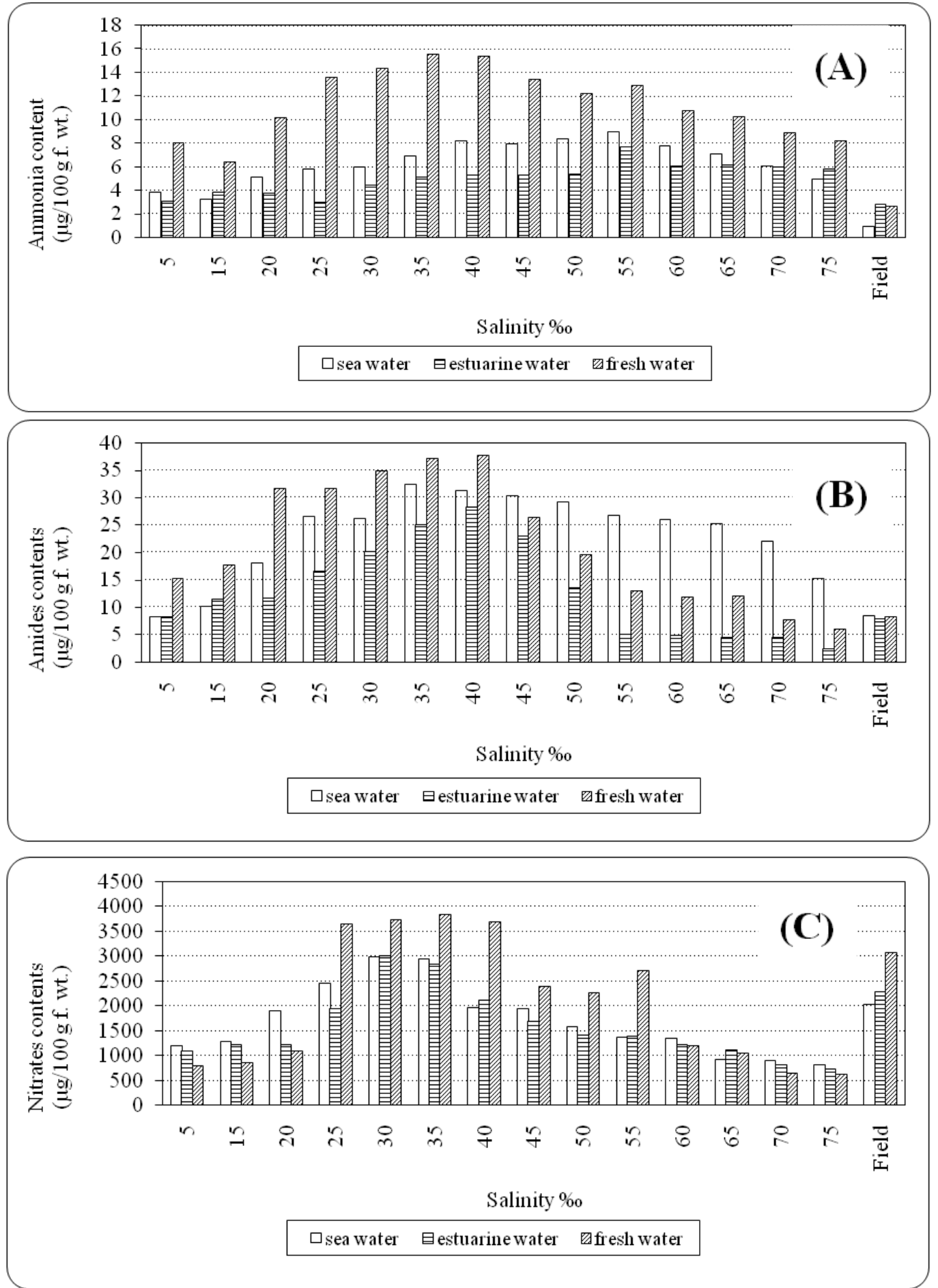

Figure 3. Effect of different salinities on ammonia (A), amides (B) and nitrates (C) contents of Cladophora glomerata collected from different habitats. 
Physiological response of native ecotypes of Cladophora glomerata (L.) Kützing (Chlorophyceae) in relation to..
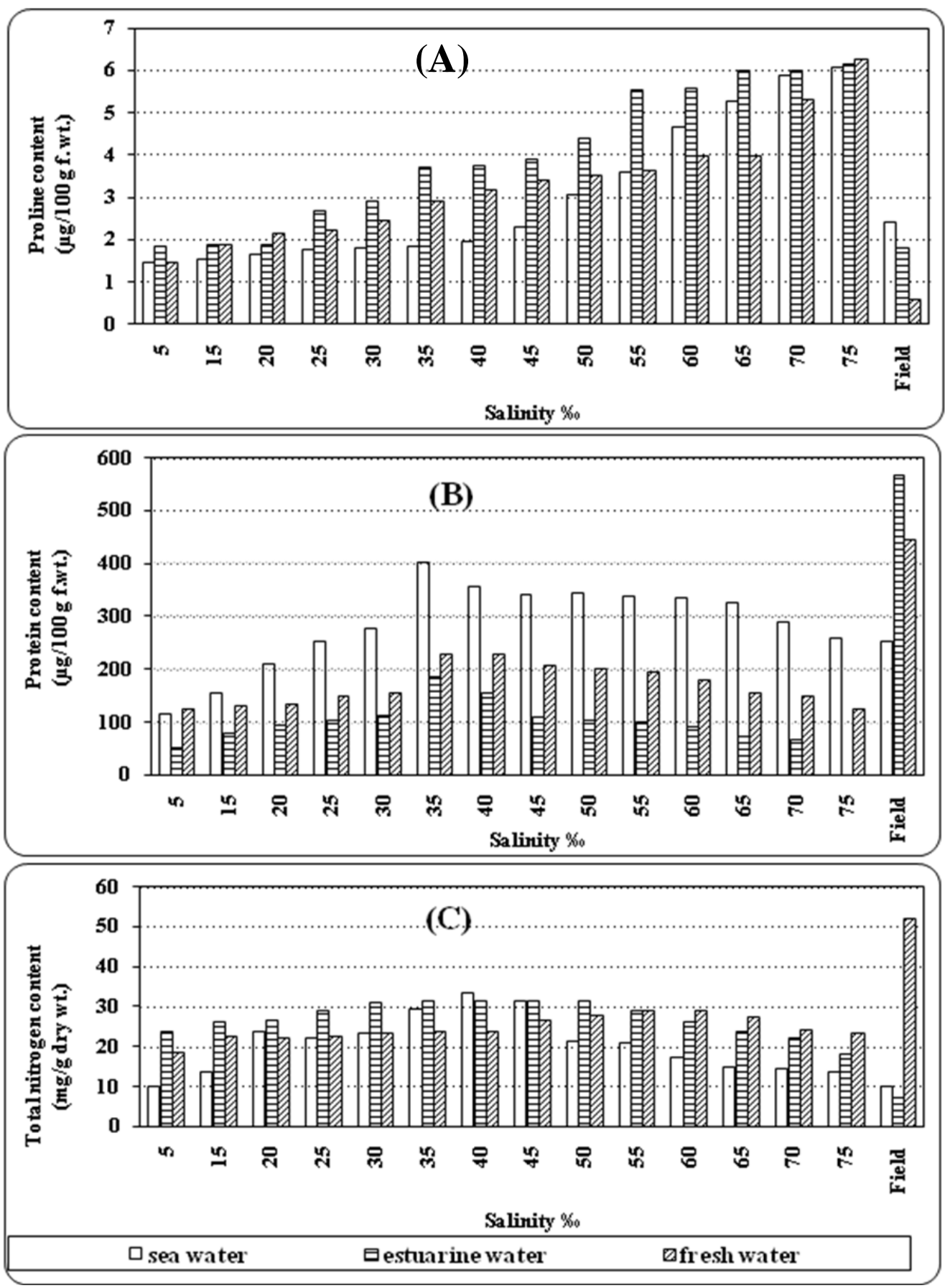

Figure 4. Effect of different salinities on proline (A), protein (B) and total nitrogen contents (C) of Cladophora glomerata collected from different habitats. 
suggests the existence of costs and limits of plasticity (Valladares et al., 2007). However, costs may vary in magnitude depending on environmental conditions and they seem to be significant in stressful environments (Steinger et al., 2003). As Charles R. Darwin in 1859 said "it is not the strongest of the species that survive or the most intelligent but the ones most responsive to change", the ecological breadth of species may partly explained by their capacity to show plastic response to environment (Sultan, 2001; Gonzalez and Gianoli, 2004; Saldana et al., 2005).

Not only Cladophora glomerata could live over a wide range of salinities- as it was collected from fresh, estuarine and sea water, but also it showed promising quantities of fitness component in the three habitats (Table 2). At the same time, it confirmed a good example for adaptation to the microcomponent of the surrounding water. Although there are great differences in most mineral fractions of the three types of water (Table 1), Cladophora glomerata showed promising contents of most fitness components. Moreover, when it exposed to salinity stress, it still sustained a hopeful contents of fitness component (Figures 2, 3 and 4).

From the above discussion, it is noteworthy to suggest Cladophora glomerata a "salinity generalist" (a species that able to maintain fitness over a wide range of salinities), equable to ecological generalist that was suggested by many authors for a species that able to maintain fitness in over wide range of environments (e. g. Lortie and Aarssen, 1996; Sultan, 2001; El-Kenany, 2006).

\section{References}

Abdel-Basset, R. (1986). Photosynthesis and some related metabolic processes as influenced by salinization treatment. Ph. D. thesis, Faculty of Science, Assuit University, Assuit, Egypt.

Abdel-Kareem, M. S. M. (1997). Growth and osmoregulation of Chlorella salina and Dunaliella salina under the interaction of salinity and inorganic nitrogen sources. Journal of the Union of Arab Biologists Cairo 4(B) Botany, 85-103.

Abdel-Rahman, M. H. M.; Ali, R. M. and Said, H. A. (2005). Alleviation of $\mathrm{NaCl}$-induced effect on Chlorella vulgaris and Chlorococcum humicola by riboflavin application. International Journal of Agriculture and Biology, 7(1):58-62.

Allam, M. M. (1989). Studies on the contribution of organic solutes to osmotic balance in Enteromorpha intestinalis (L.) Link. M. Sc. thesis, Faculty of Science, Alexandria University, Alexandria, Egypt.

Allam, M. M. (1994). Studies on native ecotypes of Enteromorpha intestinalis under salinity stress. Ph. D. thesis, Faculty of Science, Alexandria University, Alexandria, Egypt.

Bates, L. S.; Waldern, R. R. and Teare, I. D. (1973). Rapid determination of free proline for water stress studies. Plant Physiology, 39:205-207.

Egyptian J. of Phycol. Vol. 9, $2008 \quad$ - 124 - 
Barakat, S. T.; Hatata, M.; Shehata, S. and Addel, A. A. (1986). Effect of nitrogen starvation and nitrate application on some metabolic process in barley seedlings (Hordium vulgare L.). Bulletin of the Faculty of Science, Alexandria University, 26(4):15-31.

Boalch, G. T. (1961). Studies of Ectocarpus in culture. I. Introduction and methods of obtaining unialgal bacteria free cultures. Journal of Marine Biology, 41(2): 279-286.

Booth, R. L. and Lobring, L. B. (1973). Evolution of the autoanalyzer 11-A progress report. In: Advances in automated analysis 1972. Technician International Congress 8:7. Tarrytown New, York.

Chapman, S. B. (1976). Methods in Plant Ecology. Blackwell Scientific Publications, Oxford, John Wiley and Sons.

Ekelund, N. G. A. (2000). Interactions between photosynthesis and 'lightenhanced dark respiration' (LEDR) in the flagellate Euglena gracilis after irradiation with ultraviolet radiation. Journal of Photochemistry and Photobiology, 55(1):63-69.

El-Kenany, E. T. (2006). Phenotypic plasticity and genetic differentiation between ecological populations of Polygonum equisetiforme Sibth. \& Sm. In Egypt. Ph. D. thesis, Faculty of Science, Alexandria University, Alexandria, Egypt.

Fabregas, J.; Herrero, C.; Abalde, J.; Liano, R. and Cabezas, B. (1986). Biomass production and biochemical variability of the marine microalga Dunaliella tertiolecta (Dutcher) with high nutrient concentrations. Aquaculture, 53:101-113.

Fretwell, S. D. (1972). Population is a seasonal environment. Princeton University Press. Princeton.

Gonzalez, A. V. and Gianoli, E. (2004). Morphological plasticity in response to shading in three Convolvulus species of different ecological breadth. Acta Oecologia, 26:185-190.

Gorham, J. (1995). Mechanism of salt tolerance of halophytes. In: Halophytes and biosaline agriculture. (Eds.): R. Choch-Allah, C. V. Malcolm and A. Hamdy, 207-223. Marcel Dekker Inc. New York.

Gul, B. and Khan, M. A. (2008). Effect of compatible osmotic and plant growth regulators in alleviating salinity stress on seed germination of Allenrolfea occidentalis. Pakistan Journal of Botany, 40(5):1957-1964.

Hartee, E. F. (1972). Determination of protein: A modification of the Lowery method that gives a linear photometric response. Annals of Biochemistry, 48:422-427.

Imamul-Huq, S. M. and Larher, F. (1985). Dynamics of $\mathrm{Na}^{+}$and proline accumulation in salt-treated Vigna sinensis (L.) and Phaseolus aureus (L.). Plant Physiology, 119:133-147.

Johnson, C. M. and Ulrich, U. (1950). Determination of nitrate in plant material. Analysis, 22:1526-1531. 
Kamer, K. and Fong, P. (2000). A fluctuating salinity regime mitigates the negative effects of reduced salinity on the estuarine microalga Enteromorpha intestinalis (L.) Link. Journal of Marine Biology and Ecology, 245(1):53-69.

Karestn, U. and Kirst, G. O. (1989). Intracellular solutes photosynthesis and respiration of the green alga Bilindingia minima in response to salinity stress. Botanica Acta, 102:123-128.

Karesten, U. and Kirst, G. O. (1990). Incomplete turgor pressure regulation in the terrestrial red alga Bostrychia scorpiods. Plant Science, 61:29-36.

Kirst, G. O. 1990. Salinity tolerance in ecotypic marine algae. Annual Review of Plant Physiology, 41:21-52.

Larkum, A. W. D. and Wood, W. F. (1993). The effect of $U V-B$ radiation on photosynthesis and respiration of phytoplankton, benthic macroalgae and seagrasses. Photosynthesis Research, 36(1):17-23.

Lortie, C. J. and Aarssen, L. W. (1996). The specialization for phenotypic plasticity in plants. International Journal of Plant Science, 157(4):484-487.

Martins, I.; Oliveira, J. M.; Flindt, M. R. and Marques, J. C. (1999). The effect of salinity on the growth rate of the macroalga Enteromorpha intestinalis (Chlorophyta) in the Mondego estuary (west Portugal). Acta Oecologia, 20(4):259-265.

Muratl, T.; Akazaw, T. and Shikikon, F. (1968). Enzymic mechanism of starch break down in germinating rice seeds. Plant Physiology, 43:1899-1905.

Naguib, M. I. (1964). Effect of sevin ion carbohydrate and nitrogen metabolism during the germination of cotton seed. Indian Journal of Experimental Biology, 2:149-157.

Pintado, A.; Valladares, F. and Sancho, L. G. (1997). Exploring phenotypic plasticity in the lichen Ramalina capitata: morphology, water relations and chlorophyll content in north and south-facing populations. Annals of Botany, 80:345-353.

Rijstenbil, J. W.; Mur, L. R.; Wijnholds, J. A. and Sinke, J. J. (1989a). Impact of a temporal salinity decrease on growth and nitrogen metabolism of the marine diatom Skletonema costatum in continuous cultures. Marine Biology, 101:121-129.

Rijstenbil, J. W.; Wijnholds, J. A. and Sinke, J. J. (1989b). Implication of salinity fluctuations for growth and nitrogen metabolism of the marine diatom Ditylum brightwillii in comparison with Skletonema costatum. Marine Biology, 101:131-141.

Russell, G. and Balton, J. J. (1975). Euryhaline ecotype of Ectocarpus siliculosus. Lumyb. Estaurine Coastal and Marine Science, 3:91-94.

Saldana, A.; Gianoli, E. and Lusk, C. H. (2005). Ecophysiological response to light availability in three Blechnum species (Pteridophyta, Blechnaceae) of different ecological breadth. Oecologia, 145:252-257.

Schlichting, C. D. (1986). The evolution of phenotypic plasticity in plants. Annual Review and Ecology and Systematics, 17:667-693. 
Simonsen, R. (1965). Okologische Benerkungen zu der zur Aerophilie der Datomeen. International Revueges de Hydrobiologie, 50:49-56.

Starr, R. C. (1978). The culture collection of algae at the University of Texas at Austin. Journal of Phycology, 14:47-100.

Stein, J. R. (1973). Hand-Book of phycological methods. Culture methods and growth measurement. 334-335. Cambridge University Press, London.

Steinger, T.; Roy, B. A. and Stanton, M. L. (2003). Evolution in stressfull environments ii. Adaptive value and costs of plasticity in response to low light in Sinapis arvensis. Journal of Evolutionary Biology, 16:313-323.

Sultan, S. E. (1995). Phenotypic plasticity and plant adaptation. Acta Botanica Neerlandica, 44:636-638.

Sultan, S. E. (2001). Phenotypic plasticity for fitness component in Polygonum species of contrasting ecological breadth. Ecology, 82(2):328-343.

Thomas, D. N.; Collirs, J. C. and Russell, G. (1990). Interpopulation difference in the salt tolerance of two Cladophora species. Estuarine Costal Shelf Science, 30:201-206.

Valladars, F.; Gianoli, E. and Gomez, J. M. (2007). Ecological limits to plant phenotypic plasticity. New Phytologist, 176:749-763.

van Kluenen, M. and Fischer, M. (2005). Constraints on the evolution of adaptive phenotypic plasticity in plants. New Phytologist, 166:49-60.

van Kluenen, M. and Fischer, M. (2007). Progress in the detection of costs of phenotypic plasticity in plants. New Phytologist, 176:727-730.

Ziska, L. H. and Teramura, A. H. (1992). CO2 Enhancement of Growth and Photosynthesis in Rice (Oryza sativa). Modification by Increased Ultraviolet-B Radiation. Plant Physiology, 99(2):473-481.
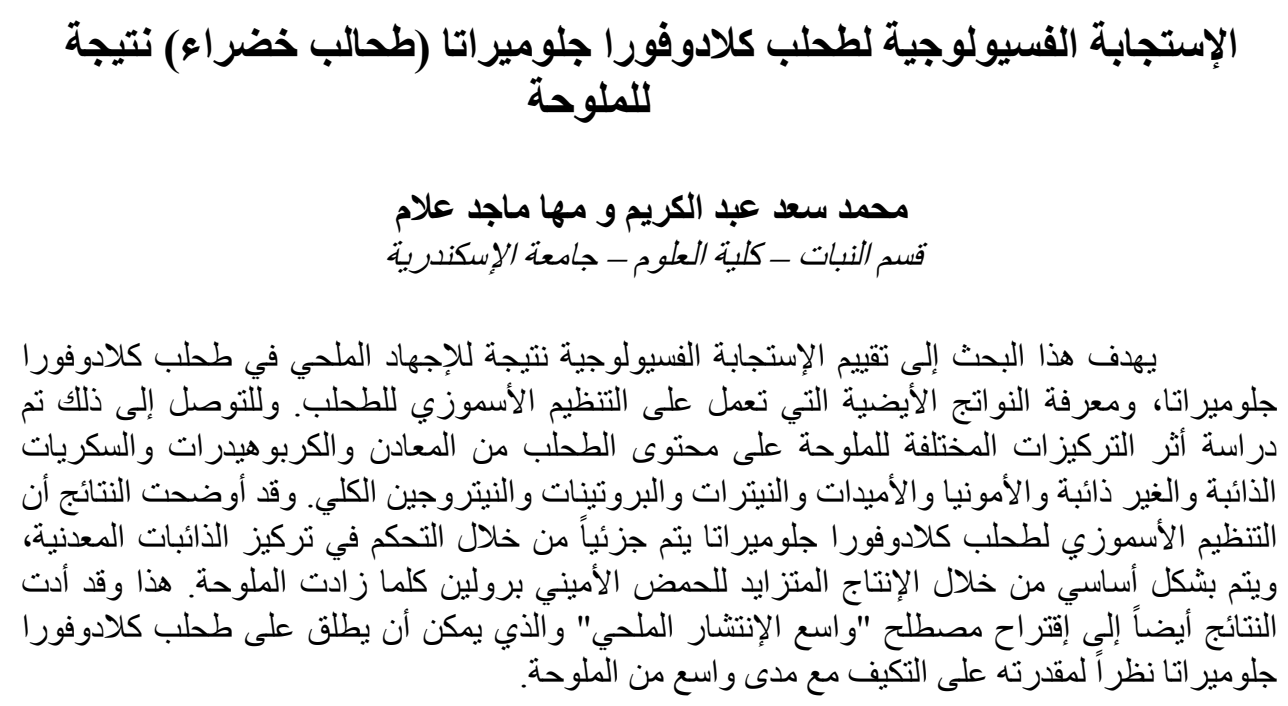